\title{
Dermatophilosis in sheep raised under rotational grazing systems on irrigated pastures in the Brazilian semiarid region
}

\author{
Vanessa Diniz Vieira ${ }^{1 *}$ Franklin Riet Correa $^{1,2}$ Vinícius Longo Ribeiro Vilela $^{3}$ \\ Márcia Alves de Medeiros ${ }^{1}$ Dayana Firmino de Morais ${ }^{4}$ Antonielson dos Santos ${ }^{5}$ \\ Thaís Ferreira Feitosa ${ }^{1}$ João Leite de Almeida Neto ${ }^{5}$
}

1Programa de Pós-graduação em Medicina Veterinária, Universidade Federal de Campina Grande (UFCG), 58.108-110, Patos, PB,
E-mail: vanessa.veterinaria@hotmail.com. "Corresponding author.
${ }^{2}$ Instituto Nacional de Investigación Agropecuaria (INIA), La Estanzuela, Colonia, Uruguay.
${ }^{3}$ Departamento de Medicina Veterinária, Instituto Federal da Paraíba (IFPB), Sousa, PB, Brasil.
${ }^{4}$ Programa de Pós-graduação em Zootecnia, Universidade Federal de Campina Grande (UFCG), Patos, PB, Brasil.
${ }^{5}$ Graduando em Medicina Veterinária, Departamento de Medicina Veterinária, Instituto Federal da Paraíba (IFPB), Sousa, PB, Brasil.

ABSTRACT: Seventeen outbreaks of dermatophilosis are reported from three farms affecting Santa Inês and Santa Inês $x$ Dorper sheep that were reared in irrigated areas with rotational grazing at a stocking rate of 50 to 100 sheep per hectare, in the Brazilian semiarid region. Most outbreaks occurred after rains and affected sheep of different ages, with morbidity rates of $0.77 \%$ to $31 \%$. Clinical signs were dermatitis with crusts that stood out easily and left areas of alopecia. Dermatophilus congolensis was isolated in cultures in $5 \%$ sheep blood agar by means of Haalstra's method. Histologically, the epidermis showed extensive multifocal areas of ortho and parakeratotic hyperkeratosis with intracorneal microabscesses and presence of D. congolensis. Sheep affected were isolated from the flocks and they recovered after treatment with 70,000IU of procaine penicillin $\mathrm{G}$ and 70mg of dihydrostreptomycin sulphate per $\mathrm{kg}$ of bodyweight. Dermatophilosis is a frequent endemic disease in rotational grazing systems with irrigated pastures and high stocking rates, which occurs with higher frequency after rains and can be controlled efficiently through isolation of the affected sheep, followed by application of a single dose of penicillin and streptomycin. Key words: dermatitis, Dermatophilus congolensis, environment, high stocking rate, management.

Dermatofilose em ovinos criados em sistemas de pastejo rotacionado em pastagens irrigadas no semiárido brasileiro

RESUMO: Relatam-se 17 surtos de dermatofilose em três fazendas de ovinos da raça Santa Inês e Santa Inês x Dorper criados em áreas irrigadas com pastoreio rotativo, com lotações de 50 a 100 ovinos por hectare, no município de Belém do São Francisco, Pernambuco. Os surtos ocorreram após períodos de chuvas, afetando ovinos de diversas idades, com morbidade de 0,77\% a 31\%. Os sinais clínicos caracterizaram-se por dermatite com formação de crostas que se destacavam com facilidade, deixando áreas de alopecia. Em culturas em meio de ágar sangue ovino a 5\% foi isolado Dermatophilus congolensis. Na histologia, a epiderme apresentava extensas áreas multifocais de hiperqueratose orto e paraqueratótica, com microabcessos intracorneais e presença de D. congolensis. Os animais foram separados do rebanho e tratados com $70.000 U$ I de benzilpenicilina procaina e $70 \mathrm{mg}$ de sulfato de diidroestreptomicina por $\mathrm{kg}$ de peso vivo e todos se recuperaram. Conclui-se que a dermatofilose é uma doença endêmica frequente em ovinos em sistemas de pastejo rotativo irrigado e altas lotações, que ocorre com maior frequência após perídos de chuva e que pode ser controlada eficientemente com isolamento dos animais seguido de uma única aplicação de penincilina e estreptomicina.

Palavras-chave: alta lotação, ambiente, dermatite, Dermatophilus congolensis, manejo.

\section{INTRODUCTION}

Dermatophilosis is a disease that primarily affects cattle, goats, sheep and horses (PEREIRA \& MEIRELES, 2007; RADOSTITS et al., 2010). It is caused by Dermatophilus congolensis, which is a filamentous and branched Gram-positive coco-bacillus within the actinomycetes group that causes exudative dermatitis with crusts that stand out easily (WABACHA et al., 2007). Bacterium is considered to be aerobic or facultative anaerobic (NORRIS et al., 2008). It presents mobile zoospores, which under suitable conditions of 
elevated temperature and humidity, can proliferate and develop disease (HYSLOP, 1979). Although, D. congolensis is present in clinically normal skin of many animals, it acts as an opportunistic agent under conditions of immunosuppression and food shortage (QUINN et al., 2005; MACÊDO et al., 2008).

Animals have natural barriers against penetration of microorganisms through the skin, including hair, fat produced by the sebaceous glands and the epithelial stratum corneum. When these barriers are compromised, $D$. congolensis is able to penetrate the epidermis and establish infection (DALIIS et al., 2009). Microenvironmental conditions that interfere with normal mechanisms of surface protection, such as sebaceous secretions, also lead to activation of dormant zoospores. When these are activated, they produce germ tubes that develop into filaments that invade the epidermis (WOLDEMESKEL \& MERSHA, 2010).

Dermatophilosis is widely distributed around the world, in humid tropical and subtropical regions (HYSLOP, 1979; SHAIBU et al., 2010). In Brazil, dermatophilosis in sheep was first studied in the state of São Paulo, where the prevalence was $95.8 \%$, affecting both young animals and adults (ARANTES et al., 1977). In the Federal District of Brazil, an outbreak among adult Santa Inês sheep was studied (CASTELO BRANCO et al., 2012). In the semiarid region of Paraíba, outbreaks occurring in April, i.e. at the end of the rainy season, have been reported. Nevertheless, isolated cases have been observed both in the rainy and in the dry season (MACÊDO et al., 2008). Disease occurs both in native and in cultivated pastures, and both in wool sheep (PEREIRA \& MEIRELES, 2007) and in hair sheep (MACÊDO et al., 2008), but has not been described in sheep in irrigated pastures.

The objective of this study was to report outbreaks of dermatophilosis affecting hair sheep on irrigated pastures with rotational grazing at high stocking rates, on three farms in the municipality of Belém de São Francisco, in the semiarid region of the state of Pernambuco, Brazil.

\section{MATERIALS AND METHODS}

Outbreaks of dermatophilosis affecting sheep occurred in three farms in the municipality of Belém de São Francisco, state of Pernambuco, between January 2013 and November 2015. These farms are located in the semiarid region, with an average temperature of $26^{\circ} \mathrm{C}$, humidity of approximately $50 \%$, insolation of 2800 hours per year, evaporation of $2000 \mathrm{~mm}^{3}$ per year, total cumulative precipitation of $350-800 \mathrm{~mm}^{3}$ per year and a long dry season, from May or June until February or March of the following year (MOURA et al., 2013).

All the farms visited had Santa Inês and crossbred Santa Inês x Dorper sheep that were reared in rotational grazing systems with irrigation. Total cumulative precipitation in the municipality of Belém de São Francisco, Pernambuco, was 322.3mm in 2013, $239.8 \mathrm{~mm}$ in 2014 and $223.4 \mathrm{~mm}$ in 2015 (Figure 1). Absolute monthly temperature range was from $14^{\circ} \mathrm{C}$ to $37^{\circ} \mathrm{C}$, with an average minimum temperature of $21^{\circ} \mathrm{C}$ and an average maximum temperature of $33.5^{\circ} \mathrm{C}$.

On farm 1, in May 2013, there were 750 animals divided into two herds (lactating ewes and non-lactating ewes), with a stocking rate of 65 sheep ha-1. Pastures consisted of coast-cross grass (Cynodon dactylon) and were divided in 23 paddocks of 0.5 ha each. Animals were kept in each paddock for three days and then the paddock was left to rest for approximately 35 days. In January 2014, the number of animals increased to 1097 and the stocking rate to 89 sheep ha-1. In March 2014, the number of paddocks was increased to 32 of 0.5 ha each, and the animals entered the new paddocks in April 2014. In August 2014, the number of animals decreased to 859 and the stocking rate to 50 sheep ha-1. Farm 2 had a herd of about 600 animals, which were all reared together, without separation according to category, except that recently lambed sheep were separated in a stall with no access to grazing for seven days. The stocking rate was 100 sheep ha-1. There were 24 paddocks of $0.25 \mathrm{ha}^{-1}$ each. Animals were kept in each paddock for two days and then the paddock was left to rest for 48 days. Pastures comprised six paddocks of Panicum maximum var. Mombaça, eight of Panicum maximum var. Aruana and ten of coast-cross grass (Cynodon dactylon). Sheep received supplementation consisting of ground corn, soybeans and mineral salt, but this was insufficient and poorly distributed in a few troughs. Consequently, much of the herd did not get access to it.

On farm 3, the flock comprised approximately 500 sheep of different ages, all reared together. The stocking rate in May 2013 was 72 sheep $\mathrm{ha}^{-1}$. Pastures consisted of P. maximum var. Aruana, distributed in seven paddocks of 1 ha each. Animals were kept in each paddock for four days and then the paddock was left to rest for about 28 days.

In the three farms, the sheep remained in the pasture during the day and were enclosed in pens at night, visits were made to these three farms to obtain epidemiological and clinical data. After each outbreak, the approximate number of sick animals was reported by the farmers. Crusted lesions from 10 


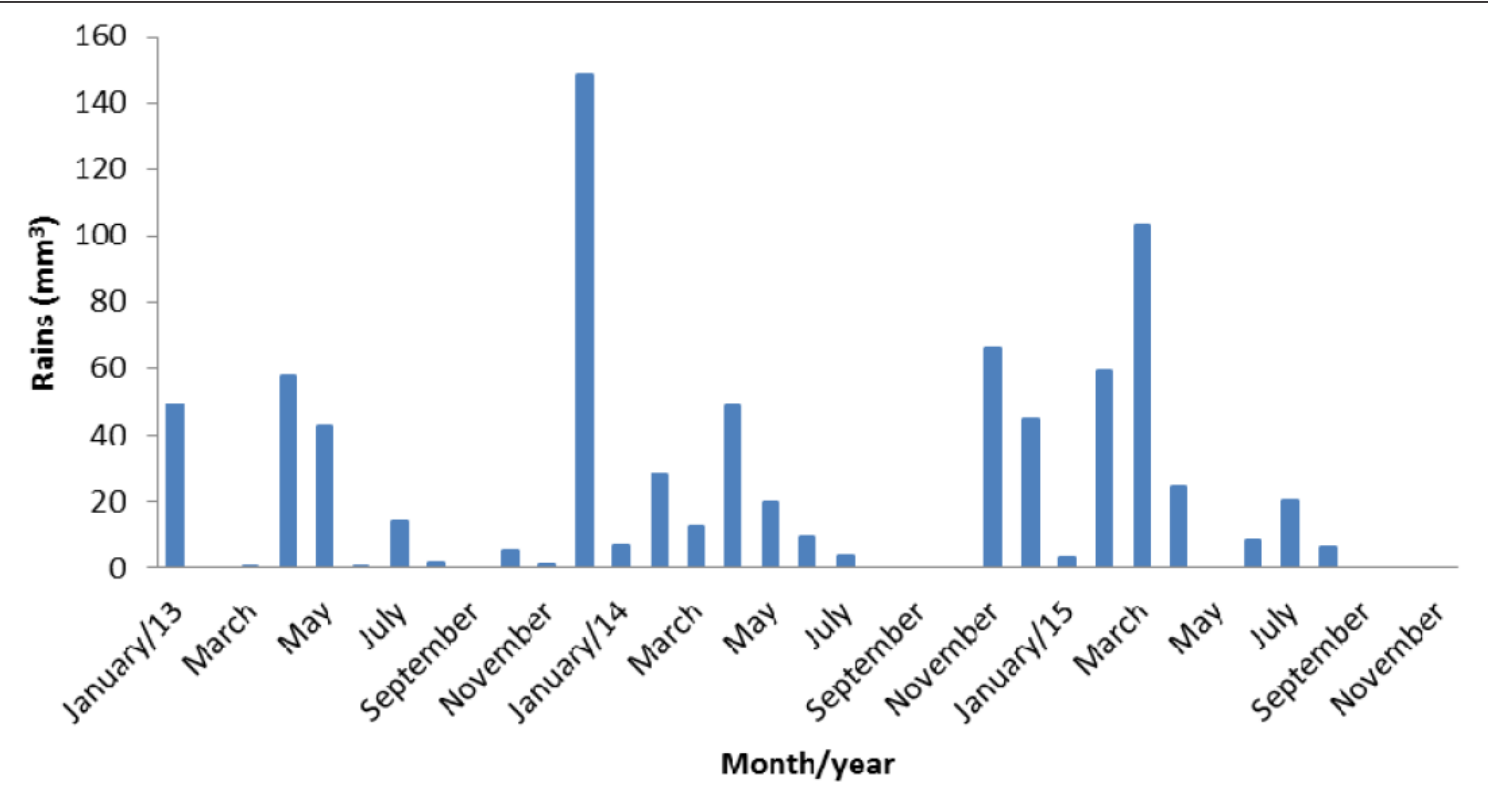

Figure 1 - Precipitation occurred between January 2013 and November 2015 in the municipality of Belem de São Francisco.

sheep were collected with the aid of gloves, tweezers and sterile plates for direct smear examination and cultures. After material had been crushed with a scalpel and moistened with sterile saline solution, direct impressions of the lower face of the crust were made on slides that were stained by means of Giemsa method. Crusts were also placed on plates with $5 \%$ blood agar, using Haalstra's method (QUINN et al., 1994). One sheep that died on farm 2 was necropsied and samples of skin, organs of abdominal and toraxic cavities and central nervous system were fixed in $10 \%$ buffered formalin, embedded in paraffin and cut at $4-5 \mathrm{~m} \mu$ and stained by hematoxylin and eosin.

After disease diagnosis of sheep were treated with AGROVET PLUS ${ }^{\circledR}$ at a dose of $2 \mathrm{~mL}$ $10 \mathrm{~kg}^{-1}$ of body weight. This solution contained $70,000 \mathrm{IU}$ of procaine benzylpenicillin, $70 \mathrm{mg}$ of dihydrostreptomycin sulfate, $1.2 \mathrm{mg}$ of piroxicam and $3.46 \mathrm{mg}$ of procaine hydrochloride per $\mathrm{kg}$ of body weight, in a single dose.

\section{RESULTS}

On farm 1, from May 2013 to August 2015 , there were 11 outbreaks of dermatophilosis, all associated with the occurrence of rains in the previous 1-2 weeks (Table 1). Distribution of the rainfalls in the region is presented in Figure 1. Morbidity varies from
$0.77 \%$ to $13.6 \%$ but without mortality. Lambs and lactating ewes were more often affected (Table 1). All the animals affected recovered after treatment with a single dose of 70,000IU of procaine benzylpenicillin and $70 \mathrm{mg}$ of dihydrostreptomycin sulfate. In all the outbreaks, the animals affected were treated and isolated from the herd for a period of 21 days, until the lesions disappeared. Over the two-year period, cost of treatment per animal was US\$ 3.27.

On farm 2, there were two outbreaks: in May, 2013, and in January, 2014. In May 2013 the morbidity rate was $30 \%(180 / 600)$ (Table 1$)$ with a mortality of $10 \%(60 / 600)$ due probably to nutritional deficiency associated with dermatophilosis. All cases were treated in the same way as described for farm 1 . In February 2014, all the sheep were sold because of the high mortality rate despite the frequent treatment for gastrointestinal nematodes.

On farm 3, there were four outbreaks of dermatophilosis between May 2013 and January 2014, with morbidity rates of $1.67 \%$ to $31 \%$ (Table 1 ). The outbreaks were controlled with treatment similar to that used on farms 1 and 2. In April 2014 the owner sold $70 \%$ of the animals.

The clinical signs were characterized by alopecia and crusts throughout the body, especially on the ears, head, back, and fore and hind limbs (Figure 2 A-C). Crusts were easily detached by 
Table 1 - Data on dermatophilosis outbreaks on three farms in the municipality of Belém de São Francisco, Pernambuco, between January 2013 and November 2015.

\begin{tabular}{|c|c|c|c|}
\hline Outbreaks (month and year) & $\begin{array}{l}\text { Rainfall volume (mm) occurred } 1-2 \\
\text { weeks before the outbreaks }\end{array}$ & Category of animalAffected & $\begin{array}{c}\text { Approximate prevalence } \\
(\%)\end{array}$ \\
\hline \multirow[t]{3}{*}{ May/13 } & 42.5 & Lactating sheep & 1.55 \\
\hline & & Lambs & 0.77 \\
\hline & & Non- lactating sheep & 0.77 \\
\hline Oct $/ 13$ & 5.2 & Non- lactating sheep & 1.45 \\
\hline Nov/13 & 25 & Non -lactation sheep & 2.38 \\
\hline \multirow[t]{2}{*}{$\mathrm{Jan} / 14$} & 148.6 & Lactating sheep & 13.67 \\
\hline & & Lambs & 9.11 \\
\hline Mar/14 & 12.6 & Lactating sheep & 3.8 \\
\hline Aug/14 & 9 & Lambs & 5.82 \\
\hline Nov/14 & 66 & Lactating sheep & 1.02 \\
\hline \multirow[t]{2}{*}{$\mathrm{Feb} / 15$} & 31 & Lactating sheep & 6.41 \\
\hline & & Lactating sheep & 2.56 \\
\hline May/15 & 24.4 & Lactating sheep & 6.54 \\
\hline $\mathrm{Jul} / 15$ & 20 & Non- lactating sheep & 2.65 \\
\hline Aug/15 & 6 & Lactating sheep & 3.53 \\
\hline \multirow{3}{*}{ May/13 } & 42.5 & Lactating sheep & 3.33 \\
\hline & & Non- lactating sheep & 6.66 \\
\hline & & Lambs & 20 \\
\hline $\mathrm{Jan} / 14$ & 148.6 & Non- lactating sheep & 10 \\
\hline \multicolumn{4}{|l|}{--------- } \\
\hline May/13 & 42.5 & Lactating sheep & 4 \\
\hline $\mathrm{Jul} / 13$ & 14 & Lactating sheep & 1.67 \\
\hline Nov/13 & 25 & Non Lactating sheep & 3.83 \\
\hline \multirow[t]{3}{*}{$\mathrm{Jan} / 14$} & 148.6 & Lambs & 17.7 \\
\hline & & Non- lactating sheep & 31 \\
\hline & & Lactating sheep & 21.1 \\
\hline
\end{tabular}

means of a simple twist of the tuft of hair, leaving an apparently normal alopecic skin (Figure 2C). On Farm 2, there were 60 deaths (10\% of the flock). During this outbreak the nutritional status of the sheep was poor and the animals affected showed cachexia, alopecia, diffuse crusts throughout the body and slight pruritus. On farms 1 and 3, most of the animals had good nutritional status and the lesions mainly affected the ears and back.

One animal that died on farm 2 presented cachexia and had areas of alopecia in the region of the thoracic limbs. Small areas of crust with whitish appearance, which came off easily, were seen on the ears. Necropsy showed widespread subcutaneous edema comprising approximately $50 \mathrm{ml}$ of translucent fluid in the abdominal and thoracic cavities and cheesylooking nodules in the submandibular lymph node (caseous lymphadenitis). Histological examination on the epidermis showed extensive multifocal areas of ortho and hyperkeratosis, and parakeratotic pseudoepitheliomatous hyperplasia and acanthosis (Figure 2D) with intracorneal microabscesses and presence of basophilic filamentous structures that were morphologically consistent with $D$. congolensis. Dermis showed moderate dermatitis (Figure 2D) with infiltrate by neutrophils and rare lymphocytes and plasma cells, mainly located near vessels. The microscopic examination of the crusts showed basophilic filamentous structures, with a characteristic pattern of flattened coccus forming chains, morphologically similar to D. congolensis. After 48 hours of incubation at $37^{\circ} \mathrm{C}$ in an atmosphere of $5-10 \% \mathrm{CO}_{2}$, cultures presented hemolytic colonies with a yellowish smooth appearance and circular shape. Under the microscope, the bacteria observed were Gram-positive, with production of branched filaments, characteristics of $D$. congolensis. 


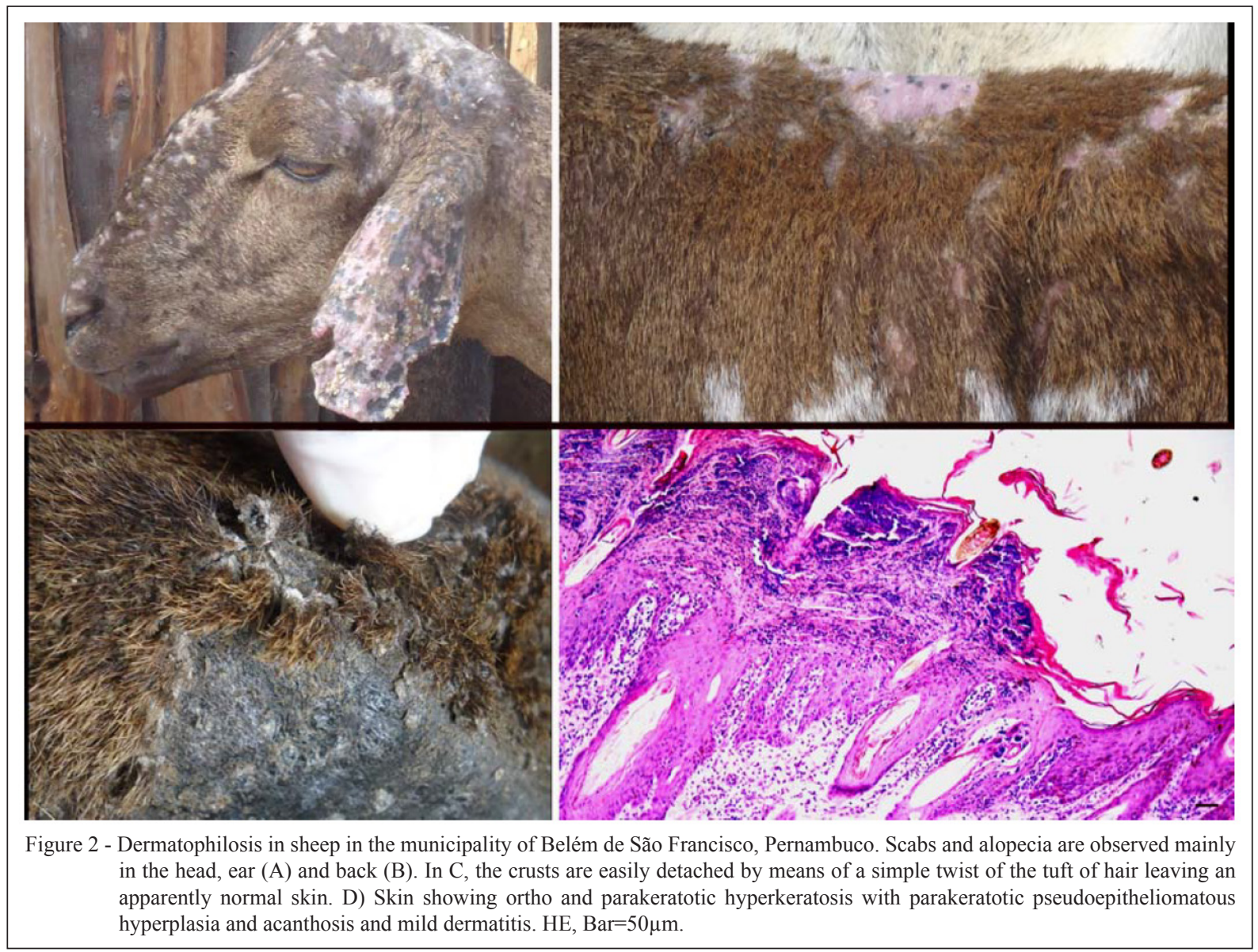

\section{DISCUSSION}

These results showed that dermatophilosis is a common endemic disease in some sheep flocks reared in the Brazilian semiarid region under rotational systems with irrigation. Multiple factors appear to be involved in pathogenesis of the dermatophilosis (MAULDIN \& PETERS-KENNEDY, 2016). It is probably that the most important factor leading to the endemic occurrence of dermatophilosis in these farms is related to the production system, possibly due to high stocking rates in irrigated pastures and the permanence in pens at night. In the three farms studied in this report, stocking rate was of 50-100 sheep of different ages per hectare. In the semiarid region in irrigated pastures of Tifton grass the recommended stocking rate for fattening sheep, from $2-3$ months-old $(20-22 \mathrm{~kg})$ to $5-6$ months-old (34-36kg) is considered to be of 70 sheep hectare $^{-1}$ (SILVIANO \& SILVIANO, 2005).

Another important factor related to the high frequency of the disease seems to be the rainfalls that always occurred a week or two before the outbreaks were observed (Table 1). This would explain the simultaneous occurrence of outbreaks on the three farms studied, in May 2013 and January 2014, which occurred 1-2 weeks after heavy rains. Moreover, on farm 1, where the disease was studied for a longer time, all the outbreaks of greater or lesser prevalence occurred in association with rains of variable intensity during the preceding 1-2 weeks (Table 1). Other authors have reported occurrences of dermatophilosis in sheep and other species after periods of rain (PEREIRA \& MEIRELES, 2007; RADOSTITS et al., 2010). Stressors associated with rainy and warm periods cause prolonged wetting of the skin favoring the development of opportunistic bacteria and leading to imbalance of surface barriers of nonspecific immune defense (relating to $\mathrm{pH}$, fatty acids and normal flora). This allows zoospores of $D$. congolensis to invade the integument and cause dermatitis (PEREIRA \& MEIRELES, 2007; MAULDIN \& PETERS-KENNEDY, 2016). In the 
skin of infected animals, such structures become mobile zoospores that can proliferate and produce disease under favorable temperature and humidity, or else remain in latency when conditions are adverse (DALIIS et al., 2009). Despite the bacteria is present in clinically normal skin of many animals, in these outbreaks we decided to isolate the animals, as a control measure because of the possibility to increase the number of bacteria in the environment and, consequently, the possibility to develop the disease.

Nutritional deficiencies and concurrent diseases and stresses, including intestinal parasitism has also been mentioned as a predisposing factor for the development of the disease (PEREIRA \& MEIRELES, 2007; RADOSTITS et al., 2010; MAULDIN \& PETERS-KENNEDY, 2016). This seems to have been an important factor relating to the high frequency of the disease and the mortality observed on Farm 2, in which the animals had poor body condition as a result of deficient nutrition due to high stocking and bad management of the pastures that were grazed every 48 days. However, several outbreaks were observed in Farm 1, which produced $1086 \mathrm{~kg}$ of meat per hectare. In this farm nutrition of the ewes was good and the lambs were supplemented with concentrate ration in a creep feeding system. Also there was a efficient control of gastrointestinal parasites based in the correct rotation of the pastures, monthly fecal egg count, and selective antihelmintic treatments (VIEIRA et al., 2017).

Scratches from sharp vegetation can act as portals of entry for the zoospores (MAULDIN \& PETERS-KENNEDY, 2016) and dermatophilosis associated with sharp vegetation has been reported in calves in Mato Grosso do Sul, Brazil (BACHA et al., 2014). However, in those farms with irrigated pastures, sheep were grazing green soft Cynodon dactylon pastures with no possibilities to cause scratches. In addition, this grass cannot cause lesions in the back, which was a common localization of the lesions in these outbreaks. Nevertheless, because the large number of sheep to be moved twice a day it is possible the occurrence of some kind of traumatism during driving the flock to and from the pastures. Ectoparasites that can produce trauma like lice or mites were not present in the flock. Evidences of viral infections that may contribute to the development of dermatophilosis by compromising the host's immune system (MAULDIN \& PETERS-KENNEDY, 2016) were not diagnosed in any of the farms affected.

The affected sheep were treated with a single dose of 70,000IU of procaine benzylpenicillin and $70 \mathrm{mg}$ of dihydrostreptomycin sulfate, which is a low cost control method. It is clear that immediate treatment of the first cases, along with the isolation of the animals affected is the best way to control the disease, which prevents a large number of animals being affected. Despite effective treatment, new outbreaks occurred, which was probably due to continued infection among the animals and because the organism can persist in crusts in the environment for up to 42 months (RADOSTITS et al., 2010).

\section{CONCLUSION}

Dermatophilosis is an important endemic disease of sheep in irrigated systems with rotational grazing at high stocking levels (50-100 sheep ha-1). It occurs more frequently after periods of rain causing prolonged wetting of the skin.

\section{BIOETHICS AND BIOSSECURITY COMMITTEE APPROVAL}

Approved by the Ethics Committee of the Universidade Federal de Campina Grande (UFCG) with the number $002 / 2012$.

\section{REFERENCES}

ARANTES,I.G. etal. Dermatophilosis in sheep from SãoPaulo(Brazil). Mycoses, v.20, p.83-88, 1977. Available from: <http://www.scielo. br/scielo.php?script=sci_arttext\&pid=S0102093520120005005>. Accessed: June 12, 2015. doi: 10.1590/S0102-09352012000500015.

BACHA, F.B. et al. Dermatophytosis in Nelore calves in Mato Grosso do Sul. Semina: Ciências Agrárias, v.35, n.4, p.19471954, 2014. Available from: <http://www.uel.br/revistas/uel/index. php/semagrarias/article/viewFile/16821/14853>. Accessed: Jan. 19, 2017. doi: 10.5433/1679-0359.2014v35n4p1947.

CASTELO BRANCO, R.L. et al. Dermatophytosis in Santa Inês sheep in the Federal District. Arquivo Brasileiro Medicina Veterinária e Zootecnia, v.64, n.5, p.1184-1187, 2012. Available from: <https:// www.researchgate.net/publication/262745542_Dermatophylosis_in_ Santa_Ines_sheep_from_Distrito_Federal $>$. Accessed: Aug. 12, 2014. doi: 10.1590/S0102-09352012000500015.

DALIIS, J.S.et al. Distribution of lesions of dermatophilosis in catlle sheep and goats in Zaria and Jos Nigeria. Journal of Animal and Veterinary Advances, v.812, p.385-388, 2009. Available from: <http://medwelljournals.com/abstract/?doi=jav aa.2009.385.388.pdf>. Accessed: Jan. 30, 2016.

HYSLOP, N.S.G. Dermatophilosis (streptothricosis) in animals and man. Comparative, Immunology, Microbiology and Infectious Diseases, v.2, p.389-404, 1979. Available from: <https://www.mysciencework. com/publication/show/c0776cc001a1441788e3cccfedee46ed $>$. Accessed: June 12, 2015. doi: 10.1016/0147-9571(79)90082-1.

MACÊDO, J.T.S.A. et al. Skin diseases of goats and sheep in the Brazilian semi-arid region. Pesquisa Veterinária Brasileira, v.28, p.633-642, 2008. Available from: <http://www.pvb.com.br/pdf artigos/31-12-2008_20-13Vet515.pdf >. Accessed: June 12, 2014. 
MAULDIN, E.A., PETERS-KENNEDY, J. Integumentary system. In: MAXIE, G. (Ed.). Jubb, Kennedy, and Palmer's pathology of domestic animal. $6^{\mathrm{a}}$ ed. St. Louis:Elsevier, 2016, V.1. Chapt.6, p.511-736.

MOURA, M.S.B. et al. Clima e água de chuva no semiárido. Accessed: Oct. 02, 2013. Online. Available from: <http:// ainfo.cnptia.embrapa.br/digital/bitstream/CPATSA/36534/1/ OPB1515.pdf>

NORRIS, B.J. et al. Fleece rot and dermatophilosis in sheep. Veterinary Microbiology, v.1218, p.217-230, 2008. Available from: <http://fulltext.study/preview/pdf/2468857.pdf $>$. Accessed: June 20, 2015. doi: 10.1016/j.vetmic.2007.10.024.

PEREIRA, D.B., MEIRELES, M.C.A. Dermatofiolose. In: RIETCORREA, F. et al. Doenças de ruminantes e equídeos. Santa Maria: Palloti, 2007. V.1(3), p.280-286.

QUINN, P.J. et al. The Actinomycetes. In: Clinical veterinary microbiology. London: WOLF, 1994. p.144-155.

QUINN, P.J. et al. Actinomicetos. In: Microbiologia veterinária e doenças infecciosas. Porto Alegre: ARTMED, 2005. p.74-82.

RADOSTITS, O.M. et al. Clinica veterinária, um tratado de doenças dos bovinos, ovinos, suínos, caprinos e equinos. 9.ed. Rio de Janeiro: Guanabara Koogan S.A. 2010. p.1281-1282.
SHAIBU, S.J. et al. The use polymerase chain reaction in the diagnosis of dermatophilosis from catlle, sheep and catlle goats in Nigeria. Journal of Animal and Veterinary Advances, v.9, n.6, p.1034-1036, 2010. Available from: <http:/ijarm.com/pdfcopy/ feb2015/ijarm4.pdf>. Accessed: June 12, 2015.

SALVIANO, L.M.C.; SALVIANO, M.B. Engorda de ovinos em pastagens irrigadas. Petrolina: EMBRAPA, 2005. (Instruções Técnicas da Embrapa Semi-Árido. N ${ }^{0} 70$ ). Available from: $<$ https:// www.google.com.br/\#q=sistema + rotacionado+ovinos + embrapa\& $\mathrm{spf}=374>$. Accessed: May 04, 2017.

VIEIRA, V.D. et al. Controle de parasitas gastrintestinais em ovinos e análise financeira de uma fazenda com sistema de pastejo rotacionado irrigado no semiárido nordestino. Pesquisa Veterinária Brasileira, 2017 (in press).

WABACHA, J.K. et al. Atypical dermatophilosis of sheep in Kenya. Journal of the South African Veterinary Association, v.78, n.3, p.178-181, 2007. Available from: $<$ https://profiles.uonbi. ac.ke/cmulei/publications/wabacha-j-k-cm-mulei-np-gitonga-m-jnjenga-ag-thaiyah-ag-and-j-nduhiu-2007-atypi>. Accessed: Sept. 23,2014 .

WOLDEMESKEL, M.; MERSHA, G. Study on caprine and ovine dermatophilosis in Wollo Northeast Ethiopia. Tropical Animal Health Production, v.42, p.41-44, 2010. Available from: <https:// www.ncbi.nlm.nih.gov/pubmed/19548105>. Accessed: Oct. 12, 2014. doi: 10.1007/s11250-009-9383-y. 